Review Article

\title{
Evaluation of research trends in physical therapy through analysis of articles published at the world confederation for physical therapy congress
}

\author{
WAN-Hee Lee, PT, PhD ${ }^{1)^{*}}$, Ju-Ri JeOng, PT, PhD ${ }^{2)}$, Joohee Hahn, PT, MSc ${ }^{1}$ ) \\ 1) Graduate School of Physical Therapy, Sahmyook University: 815 Hwarang-ro, Nowon-gu, Seoul \\ 01795, Republic of Korea \\ 2) Musculoskeletal Center, Samsung Seoul R\&D Medical Clinic, Republic Korea
}

\begin{abstract}
Purpose] The purpose of this study was to examine research trends in physical therapy through analysis of articles published at the 2015 World Confederation for Physical Therapy Congress. [Subjects and Methods] A total of 1,339 were analyzed (presentations: 346, posters: 993). The number of papers per subject area, number of oral presentations and posters, and the number of moderator nations and regional publications were analyzed by subject area. The mean and standard deviation was used for statistical analysis. [Results] Of 1,339 items published, the musculoskeletal spine was the most common theme, with 89. Among oral presentations, 24 had cardiorespiratory themes; among poster presentations, themes related to the elderly were the most common, at 76 . Eleven moderators were from Australia, and the most frequent regional source of papers was Japan, with 238. [Conclusion] The 2015 WCPT Congress published papers in a variety of subject areas; Australia and the UK presented many papers, but Japan had the most of any region, at 238 .

Keywords: Research trend, Physical therapy, 2015 WCPT Congress
\end{abstract}

(This article was submitted Jul. 8, 2016, and was accepted Aug. 11, 2016)

\section{INTRODUCTION}

The WCPT (World Confederation for Physical Therapy) was organized in 1951 by 11 countries including Australia, Canada, Denmark, Finland, the UK, New Zealand, Norway, South Africa, West Germany, Sweden, and the United States in Denmark's capital, Copenhagen. In 1953, the first congress and the second international conference were held in London ${ }^{1,2)}$.

In 1991, the WCPT was divided into 5 regions, representing Africa, Asia and the Western Pacific, Europe, North America, and South America; in 2011, 12 subgroups were formed, for special interest in the nervous system, seniors, children, sports, and others.

As of 2015, the WCPT has participants in more than 106 Member States and more than 350,000 members. The Republic of Korea formed the KPTA (Korean Physical Therapy Association) in 1965 ${ }^{3}$, and joined the WCPT as a Member State in $1974^{4)}$.

The first WCPT Congress was held in London in 1953, followed by the United States (New York, 1956), France (Paris, 1959), Denmark (Copenhagen, 1963), Australia (Melbourne, 1967), the Netherlands (Amsterdam, 1970), Canada (Montreal, 1974), Israel (Tel Aviv, 1978), Sweden (Stockholm, 1982), Australia (Sydney, 1987), the UK (London, 1991), United States (Washington, 1995), Japan (Yokohama, 1999), Spain (Barcelona, 2003), Canada (Vancouver, 2007), and the Netherlands $(\text { Amsterdam, 2011) })^{1)}$. The 17th Congress was held in Singapore in May 2015.

In 2011, the 16th WCPT Congress, held in Amsterdam, was attended by more than 5,000 physical therapists, from more

\footnotetext{
*Corresponding author. Wan-hee Lee (E-mail: whlee@syu.ac.kr)

(C)2016 The Society of Physical Therapy Science. Published by IPEC Inc.

This is an open-access article distributed under the terms of the Creative Commons Attribution Non-Commercial No Derivatives (by-nc-nd) License $<$ http://creativecommons.org/licenses/by-nc-nd/4.0/>.
} 
than 100 countries. A total of 2,303 articles were presented, including 1,668 posters.

Papers published in journals can be used to identify trends, and are an efficient means of following academic progress and learning about advanced courses in a field ${ }^{5-7}$. Previous studies, reported the value of examining specific trends of academic research, and also suggested that reviewing publications could be a good method to explore the direction of advances and research activities ${ }^{8-10)}$.

The WCPT Congress provides information on recent research, study characteristics study, and societal trends, as well as the current direction of research in physical therapy, because high-quality papers from each country are presented.

No study analyzing international trends in physical therapy through papers published by the WCPT Congress has been reported.

The present study analyzed these papers to determine the current state and trends of physical therapy in South Korea.

\section{SUBJECTS AND METHODS}

This study analyzed a total of 1,339 research papers published at the 17th WCPT Congress, held in Singapore in May 2015, and included 346 oral presentations and 993 poster papers published in the Program Manual ${ }^{11)}$.

We analyzed presentations by country, the number of published articles according to subject, oral presentation, poster presentation, and Chair; countries participating in a Chair; and the subjects of articles by nation and percentage of published articles.

We calculated averages, frequency, and percentage by using SPSS version 12.0 (SPSS for Windows; SPSS Inc., Chicago, IL, USA).

\section{RESULTS}

Japan had the most presentations, with 238 items, followed by Australia with 139, the UK with 130, the USA with 84, Sweden with 65, and South Korea with 16 (Table 1).

Among 43 research topics, the musculoskeletal spine was the most common theme, with 89 items, followed by human movement analysis, with 88 , Older people, with 84 , pediatrics, with 68 , and stroke, with 63 ; primary health care and information management and technology were least represented, with 6 each (Table 2).

There were 346 oral presentations in the 43 subject areas, accounted for by only 30 regions. Cardiorespiratory themes were the most common, with 24 , followed by musculoskeletal spine, with 23; continuing professional development, critical care, and health promotion and wellbeing each accounted for 18; human movement analysis and musculoskeletal themes each accounted for 17 . There were 993 poster presentations, representing all 43 subject areas; presentations on older people accounted for 76, human movement analysis for 71, and pediatrics and stroke for 57 each (Table 2).

A total of 24 countries participated in a Chair, with Australia the most frequent, at 11, the USA at 10, the UK at 7, New Zealand at 6, and Singapore, South Africa, and Canada at 5 each (Table 3).

The largest number of cardiorespiratory papers was presented by Japan and Brazil, followed by Australia, with complementary therapies, Japan, with exercise physiology, Taiwan, with pediatrics, and Switzerland, with women's health (Table 2, 4). The UK published papers in 42 of the 43 subject areas, at $97.6 \%$, followed by Australia at $79.0 \%$, Japan at $74.4 \%$, the USA at $72.0 \%$, Sweden at $58.1 \%$, Brazil at $55.8 \%$, Singapore at $48.8 \%$, India at $46.5 \%$, and Canada at $44.1 \%$; South Korea published in 8 of 43 subject areas, at $18.6 \%$ (Table 5).

\section{DISCUSSION}

Research specialization has recently become important in physical therapy and rehabilitation ${ }^{12)}$. Thus, we analyzed the international status and trends of physical therapy research based on articles published at the WCPT Congress. We used this analysis to indentify the future direction of physical therapy research in Korea.

The analysis was based on the general status of published papers, oral presentations, and poster presentations, the distribution of Chair nations, and the number of articles by subject area.

The 2015 WCPT Congress published 1,339 items (346 presentation and 993 posters). This was less than the 2,303 published in 2011 in Amsterdam.

Japan published the most papers (238, with 232 poster presentations, and 6 oral presentations). Japan has made significant advance in physical therapy since the 13th WCPT Congress in Yokohama, but primarily poster presentations in 2015, possibly due to the language problems of oral presentations.

Australia published 139 items, balanced between oral and poster presentations, followed by the UK at 130, the USA at 84, and Sweden at 65; thus, English-speaking countries and the Organization for Economic Co-operation and Development (OECD) countries accounted for many items.

Notably, Brazil was the only presenting Latin American country, with 54 items. In Asia, Taiwan presented 55 items, Singapore 39, India 37, Hong Kong 23, China 22, and South Korea 16. Japan holds a dominant position in Asia, but China presented 22 articles, suggesting that the area of physical therapy is gradually developing. 
Table 1. Presentations by country $(\mathrm{N}=1,339)$

\begin{tabular}{|c|c|c|c|}
\hline Nation & Presentation & Poster & Total \\
\hline Japan & 6 & 232 & 238 \\
\hline Australia & 74 & 65 & 139 \\
\hline United Kingdom & 49 & 81 & 130 \\
\hline United States America & 20 & 64 & 84 \\
\hline Sweden & 23 & 42 & 65 \\
\hline Taiwan & 3 & 52 & 55 \\
\hline Brazil & 7 & 47 & 54 \\
\hline Canada & 15 & 26 & 41 \\
\hline Singapore & 12 & 27 & 39 \\
\hline India & 2 & 35 & 37 \\
\hline Ireland & 11 & 25 & 36 \\
\hline Switzerland & 13 & 22 & 35 \\
\hline Norway & 18 & 13 & 31 \\
\hline Netherlands & 15 & 14 & 29 \\
\hline Hong Kong & 6 & 17 & 23 \\
\hline South Africa & 10 & 12 & 22 \\
\hline China & 5 & 17 & 22 \\
\hline Finland & 7 & 11 & 18 \\
\hline New Zealand & 9 & 8 & 17 \\
\hline Nigeria & 5 & 11 & 16 \\
\hline South Korea & $\mathbf{0}$ & 16 & 16 \\
\hline Israel & 1 & 13 & 14 \\
\hline Belgium & 3 & 10 & 13 \\
\hline Denmark & 3 & 9 & 12 \\
\hline Germany & 5 & 6 & 11 \\
\hline Italy & 2 & 8 & 10 \\
\hline Colombia & 0 & 10 & 10 \\
\hline Thailand & 2 & 8 & 10 \\
\hline Egypt & 2 & 7 & 9 \\
\hline Iran & 0 & 8 & 8 \\
\hline Malawi & 1 & 7 & 8 \\
\hline Malaysia & 1 & 7 & 8 \\
\hline Portugal & 3 & 5 & 8 \\
\hline Greece & 1 & 6 & 7 \\
\hline Spain & 0 & 6 & 6 \\
\hline Iceland & 3 & 2 & 5 \\
\hline
\end{tabular}

Table 1. Continued

\begin{tabular}{|c|c|c|c|}
\hline Nation & Presentation & Poster & Total \\
\hline Philippines & 1 & 4 & 5 \\
\hline Saudi Arabia & 1 & 4 & 5 \\
\hline Slovenia & 1 & 3 & 4 \\
\hline Sri Lanka & 1 & 3 & 4 \\
\hline Bahrain & 0 & 3 & 3 \\
\hline Czech & 0 & 3 & 3 \\
\hline France & 2 & 1 & 3 \\
\hline Nepal & 0 & 3 & 3 \\
\hline Chile & 0 & 2 & 2 \\
\hline Africa & 0 & 2 & 2 \\
\hline Estonia & 0 & 2 & 2 \\
\hline Haiti & 0 & 2 & 2 \\
\hline Jordan & 0 & 2 & 2 \\
\hline Tanzania & 0 & 2 & 2 \\
\hline Pupuanewgihea & 1 & 1 & 2 \\
\hline Angola & 0 & 1 & 1 \\
\hline Apan & 0 & 1 & 1 \\
\hline Arab Emirates & 1 & 0 & 1 \\
\hline Argentina & 0 & 1 & 1 \\
\hline Austria & 0 & 1 & 1 \\
\hline Benin & 0 & 1 & 1 \\
\hline Cape Verde & 0 & 1 & 1 \\
\hline Croatia & 0 & 1 & 1 \\
\hline Ethiopia & 0 & 1 & 1 \\
\hline Malawi & 1 & 0 & 1 \\
\hline Kenya & 0 & 1 & 1 \\
\hline Kuwait & 0 & 1 & 1 \\
\hline Lebanon & 0 & 1 & 1 \\
\hline Mauritius & 1 & 0 & 1 \\
\hline Namibia & 0 & 1 & 1 \\
\hline Pakistan & 0 & 1 & 1 \\
\hline Togo & 0 & 1 & 1 \\
\hline Turkey & 0 & 1 & 1 \\
\hline 70 countries & 346 & 993 & 1339 \\
\hline
\end{tabular}

Table 2. The number of published articles according to subject

\begin{tabular}{clccc}
\hline No. & Subject & Presentation & Poster & Total \\
\hline 1 & Cardiorespiratory & 24 & 48 & 72 \\
2 & Clinical education & 9 & 19 & 28 \\
3 & Complementary therapies & 13 & 7 & 20 \\
4 & Continuing professional development & 18 & 6 & 9 \\
5 & Critical care & 18 & 9 & 27 \\
6 & Disability and rehabilitation & 13 & 9 & 22 \\
7 & Education & 7 & 21 & 28 \\
8 & Electrophysical and isothermal agents & 10 & 27 & 37 \\
9 & Exercise physiology & 8 & 25 & 33 \\
10 & Global Health & 16 & 16 & 32 \\
\hline
\end{tabular}


Table 2. Continued

\begin{tabular}{|c|c|c|c|c|}
\hline No. & Subject & Presentation & Poster & Total \\
\hline 11 & Health promotion and wellbeing & 18 & 11 & 29 \\
\hline 12 & Human movement analysis & 17 & 71 & 88 \\
\hline 13 & Mental health & 7 & 12 & 19 \\
\hline 14 & Method of teaching and learning & 15 & 26 & 41 \\
\hline 15 & Multiple sclerosis & 9 & 9 & 18 \\
\hline 16 & Musculoskeletal & 17 & 19 & 36 \\
\hline 17 & Musculoskeletal lower limb & 10 & 30 & 40 \\
\hline 18 & Musculoskeletal spine & 23 & 66 & 89 \\
\hline 19 & Musculoskeletal upper limb & 8 & 20 & 28 \\
\hline 20 & Neurology & 3 & 16 & 19 \\
\hline 21 & Non-communicable disease and risk factors & 0 & 11 & 11 \\
\hline 22 & Occupational health and ergonomics & 0 & 12 & 12 \\
\hline 23 & Older people & 8 & 76 & 84 \\
\hline 24 & Oncology and palliative care & 8 & 15 & 23 \\
\hline 25 & Orthopaedics & 7 & 34 & 41 \\
\hline 26 & Outcome measurement & 9 & 45 & 54 \\
\hline 27 & Pediatrics & 11 & 57 & 68 \\
\hline 28 & Pain and pain management & 12 & 13 & 25 \\
\hline 29 & Parkinson's & 0 & 12 & 12 \\
\hline 30 & Primary health care & 0 & 6 & 6 \\
\hline 31 & Professional issue & 0 & 16 & 16 \\
\hline 32 & Professional practice; other & 8 & 11 & 19 \\
\hline 33 & Qualifying education & 0 & 14 & 14 \\
\hline 34 & Quality and standards & 0 & 12 & 12 \\
\hline 35 & Research methodology and implementation & 7 & 16 & 23 \\
\hline 36 & Rheumatology & 0 & 9 & 9 \\
\hline 37 & Robotics and technology & 0 & 9 & 9 \\
\hline 38 & Service delivery \& emerging roles & 0 & 13 & 13 \\
\hline 39 & Spinal cord injury & 0 & 15 & 15 \\
\hline 40 & Sport and sports injuries & 7 & 39 & 46 \\
\hline 41 & Stroke & 6 & 57 & 63 \\
\hline 42 & Women's health & 0 & 28 & 28 \\
\hline 43 & Information management and Technology & 0 & 6 & 6 \\
\hline
\end{tabular}

Table 3. The number of Chairs and countries participating a Chair

\begin{tabular}{clc}
\hline Ranking No. & Chair Nation & Number \\
\hline 1 & Australia & 11 \\
2 & USA & 10 \\
3 & UK & 7 \\
4 & New Zealand & 6 \\
5 & Canada/Singapore/South Africa & 5 \\
6 & Sweden & 4 \\
7 & Netherlands & 2 \\
8 & Belgium/Brazil/China/Chile/Denmark/Finland/Iceland/Ireland/Nigeria/Philippines/ & 1 \\
\hline
\end{tabular}


Table 4. The nation according to subject and percentage of published articles

\begin{tabular}{|c|c|c|c|}
\hline \multirow{2}{*}{$\begin{array}{l}\text { Subject } \\
\text { No. }\end{array}$} & \multicolumn{3}{|c|}{ Nation (Number, \%) } \\
\hline & $1 \mathrm{st}$ & 2nd & $3 \mathrm{rd}$ \\
\hline 1 & Japan/Brazil $(14,19.4)$ & Australia $(9,12.5)$ & $\mathrm{UK}(7,9.7)$ \\
\hline 2 & Australia $(5,17.8)$ & Canada/UK/USA $(3,10.7)$ & South Africa/Ireland $(2,7.1)$ \\
\hline 3 & Australia $(6,30.0)$ & USA $(3,15.0)$ & $\mathrm{UK}(2,10.0)$ \\
\hline 4 & $\mathrm{UK}(5,20.8)$ & Australia $(4,16.6)$ & Canada/Switzerland $(3,12.5)$ \\
\hline 5 & UK $(9,33.3)$ & Australia $(4,14.8)$ & $\operatorname{USA}(3,11.1)$ \\
\hline 6 & USA $(7,31.8)$ & Singapore $(3,13.6)$ & Brazil/Japan/UK $(2,9.0)$ \\
\hline 7 & USA $(7,25.0)$ & Canada $(6,21.4)$ & Sweden $(3,10.7)$ \\
\hline 8 & Japan $(13,35.1)$ & Australia, Brazil $(4,10.8)$ & Taiwan $(3,8.1)$ \\
\hline 9 & Japan $(16,48.4)$ & Australia $(3,9.0)$ & \\
\hline 10 & Australia $(6,18.7)$ & UK $(4,12.5)$ & Japan/Ireland/USA $(3,9.3)$ \\
\hline 11 & Australia $(7,24.1)$ & UK $(4,13.7)$ & Hong Kong $(3,10.3)$ \\
\hline 12 & Japan $(40,45.4)$ & Australia $(8,9.0)$ & Sweden $(7,7.9)$ \\
\hline 13 & Norway $(3,15.7)$ & Australia/Ireland $(2,10.5)$ & \\
\hline 14 & USA $(7,17.0)$ & Australia/Canada $(6,14.6)$ & $\mathrm{UK}(3,7.3)$ \\
\hline 15 & Australia $(5,27.7)$ & Brazil $(2,11.1)$ & \\
\hline 16 & Japan $(9,25.0)$ & UK $(6,16.6)$ & Australia $(5,13.8)$ \\
\hline 17 & Japan $(9,22.5)$ & Australia $(4,10.0)$ & USA $(3,7.5)$ \\
\hline 18 & Australia $(17,19.1)$ & Sweden $(8,8.9)$ & Japan $(7,7.8)$ \\
\hline 19 & Japan $(7,25.0)$ & $\begin{array}{c}\text { Egypt/Hong Kong/ } \\
\text { Switzerland/UK/USA }(2,7.1)\end{array}$ & \\
\hline 20 & Japan/USA $(3,15.7)$ & Australia/Belgium/Sweden/UK $(2,10.5)$ & \\
\hline 21 & Nigeria $(3,27.2)$ & Japan/UK $(2,18.1)$ & Australia/India/Norway/Sweden $(1,9.0)$ \\
\hline 22 & India/ Sweden $(2,16.6)$ & & \\
\hline 23 & Japan $(39,46.4)$ & Taiwan $(8,9.5)$ & Australia/India/Singapore $(4,4.7)$ \\
\hline 24 & Ireland/Hong Kong/Japan/USA $(3,13.0)$ & Netherlands $(2,8.6)$ & \\
\hline 25 & Japan $(10,24.3)$ & Israel/Ireland/UK $(3,7.3)$ & $\begin{array}{l}\text { Denmark/Egypt/Netherland/ } \\
\text { India/Sweden }(2,4.8)\end{array}$ \\
\hline 26 & Greece/Taiwan $(5,9.2)$ & USA $(4,7.4)$ & Canada/Egypt/Japan/Sweden/UK $(3,5.5)$ \\
\hline 27 & Taiwan $(11,16.1)$ & Australia $(10,14.7)$ & Brazil $(6,8.8)$ \\
\hline 28 & UK $(9,36.0)$ & USA $(2,8.0)$ & \\
\hline 29 & Japan/Jordan/Taiwan/UK $(2,16.6)$ & Australia/Israel/Singapore/Sri Lanka $(1,8.3)$ & \\
\hline 30 & $\begin{array}{l}\text { Ireland/Lebanon/Namibia/Netherlands/ } \\
\text { Sweden/UK }(1,16.6)\end{array}$ & & \\
\hline 31 & $\mathrm{UK}(4,25.0)$ & India/Ireland/Netherlands $(2,12.5)$ & \\
\hline 32 & Japan $(5,26.3)$ & Australia $(3,15.7)$ & Finland/Sweden/Singapore $(2,10.5)$ \\
\hline 33 & Australia $(3,21.4)$ & & \\
\hline 34 & UK $(3,25.0)$ & Iran/Switzerland $(2,16.6)$ & $\begin{array}{c}\text { Australia/Hong Kong/Israel/Japan/ } \\
\text { Netherlands }(1,8.3)\end{array}$ \\
\hline 35 & UK $(5,21.7)$ & Australia $(4,17.3)$ & Netherlands $(2,8.6)$ \\
\hline 36 & $\mathrm{UK}(2,22.2)$ & & \\
\hline 37 & Japan $(4,44.4)$ & Singapore/UK $(2,22.2)$ & Belgium/New Zealand $(1,11.1)$ \\
\hline 38 & Israel/UK $(2,15.3)$ & & \\
\hline 39 & Japan/Sweden $(3,20.0)$ & UK/USA $(2,13.3)$ & $\begin{array}{l}\text { Brazil/India/Norway/Slovenia/ } \\
\text { Switzerland }(1,6.6)\end{array}$ \\
\hline 40 & Japan $(11,23.9)$ & Sweden $(5,10.8)$ & $\mathrm{UK}(4,8.6)$ \\
\hline 41 & Japan $(19,30.1)$ & Taiwan $(6,9.5)$ & Sweden $(5,7.9)$ \\
\hline 42 & Switzerland $(4,14.2)$ & Japan/Nigeria/UK/USA(3, 10.7) & Brazil/India/Slovenia(2, 7.1) \\
\hline 43 & UK $(2,33.3)$ & Australia/Finland/Iceland/Ireland $(1,16.6)$ & \\
\hline
\end{tabular}

Note the name of the subject on Table 2. One thing subject to $100 \%$, calculated as the number and a percentage of each nation published articles. 
Table 5. The nation rankings published articles in the subjects

\begin{tabular}{clcc}
\hline Ranking No. & Nation & Number & Percentage (\%) \\
\hline 1 & UK & 42 & 97.6 \\
2 & Australia & 34 & 79.0 \\
3 & Japan & 32 & 74.4 \\
4 & USA & 30 & 72.0 \\
5 & Ireland/Sweden & 25 & 58.1 \\
6 & Brazil & 24 & 55.8 \\
7 & Singapore & 21 & 48.8 \\
8 & India/Switzerland & 20 & 46.5 \\
9 & Canada & 19 & 44.1 \\
10 & Netherlands & 18 & 41.8 \\
11 & Norway & 17 & 39.5 \\
12 & China & 16 & 37.2 \\
13 & Taiwan & 15 & 34.8 \\
14 & New Zealand/Belgium/South Africa & 13 & 30.2 \\
15 & Hong Kong/Finland & 12 & 27.9 \\
16 & Israel & 11 & 25.5 \\
17 & South Korea/Germany/Denmark/Nigeria/Italy & 8 & 18.6 \\
18 & Egypt/Thailand & 7 & 16.2 \\
19 & Columbia/Malaysia & 6 & 13.9 \\
20 & Iceland/Saudi Arabia/Philippines & 5 & 11.6 \\
\hline
\end{tabular}

Note the calculated that 43 subjects published on a $100 \%$

When compared with Taiwan, India, Singapore, Hong Kong, and China, Korea requires development in the area of physical therapy. The fact that Korea presented 16 items solely as poster presentations suggests the need to overcome language barriers.

To determine whether all disciplines in physical therapy showed balanced development, we analyzed the number of papers published in each subject area. Of 1,339 papers, musculoskeletal spine (89 items) and human movement analysis (88 items) subject areas were the most commonly represented. This suggests greater interest in the analysis and treatment of neck and back symptoms, and in human movement analysis.

The second largest number of published papers was related to the older people, reflecting a global increase in the elderly population. This is expected, as physical therapy is needed by many chronic patients.

Cardiorespiratory themes accounted for 72 items and stroke for 63 . This figure suggests that physical therapy research should target the elderly, who commonly experience stroke and breathing disorders.

Primary health care, rheumatology, robotics and technology, and information management and technology were each represented by less than 10 papers.

Even though extensive research has been performed on robotics and technology in medical rehabilitation ${ }^{13}$, 14), the small number of papers presented suggests that physical therapists are still challenged by the accessibility and usability of these areas.

The invitation to serve as a Chair is recognition of authoritative expertise in a field of study. Therefore, we analyzed the number of countries invited to provide a Chair in the 2015 Congress. Of the 24 countries represented by a Chair for the 3 days and 70 sessions, Australia had the greatest number participating, in 11 sessions, followed by the USA in 10, the UK in 7 , New Zealand in 6, Singapore, Canada, and South Africa in 5 each, and Sweden in 4. Most were English-speaking countries. Taiwan and China were the non English-speaking countries invited to provide a Chair. This should inspire ongoing effort to require internationalization of physical therapy in South Korea by the KPTA.

Presentations were made in all 43 subject areas. The UK published a paper in 42 of the 43 areas (97.6\%), with the exception of occupational health and ergonomics. This showed balanced development in all fields of physical therapy. Australia published in $79.0 \%$, reflecting similarities to the UK in research and educational institutions. Australia appears to have great influence on physical therapy in the world. Japan published in $74.4 \%$, reflecting a relatively wide range of development. In particular, Japan published 39 items on older people reflective of a super-aged society ${ }^{15)}$. These publications again remind us of the challenges facing Japan.

In Asia, Singapore published in 48.8\% (21 of 43 areas), India in 46.5\% (20), China in 37.2\% (16), Taiwan in 34.8\% (15), and Hong Kong in 27.9\% (12). On the other hand, South Korea published in 18.6\% (8); this shows that physical therapy in South Korea has only developed in certain areas. The elderly population has increased exponentially in South Korea ${ }^{16)}$. 
Nonetheless, there were no reports on the elderly. Despite the importance of sports in South Korea, there were also no sports-related articles. Moreover, there were no papers published in the cardiorespiratory field, women's health, professional education system, occupational health and ergonomics, oncology and palliative care, or robotics and technology. This is a challenge for the future, showing that physical therapy should be developed in many directions.

This study has several limitations. First, this study lacked specific information about the state of physical therapy in each country because only articles published at the 2015 WCPT Congress were analyzed. Thus, the ability to accurately analyze and compare the state of physical therapy in different countries was limited. Second, the 2015 WCPT Congress was held in Singapore. Thus, it was relatively easy for Asian countries to participate. Despite these limitations, the analysis of papers provides sufficient information to determine the status of physical therapy in South Korea.

\section{REFERENCES}

1) WCPT: WCPT: The First 50years (1951-2001). World Confederation for Physical Therapy, 2001, 1-16.

2) WCPT: WCPT 60th Anniversary Publication. World Confederation for Physical Therapy, 2015, 1-32.

3) Ko KW, Lee KW, Seo SK: A study on the relation between physical therapist professionalism and organizational and job characteristics. J Kor Phys Ther, 2013, 25: $343-351$.

4) Lee SB, Moon OK, Kim JS, et al.: Study on the history of Korean physical therapy. J Int Acad Phys Ther Res, 2010, 1: 73-77.

5) Jo JS, Lee KS, Kim KN: Research trend of nutrition through analysis of articles published in Korean Journal of Community Nutrition. Korean J Community Nutr, 2011, 16: 278-293. [CrossRef]

6) Lee MS: A content analysis of articles in Journal of the Korean Society of Costume. J Korea Soc Costume, 2002, 52: 97-109.

7) Lee YS, Han YS, Kim NN: An analysis on the trends of housework researches in 3 main home economics related journals of Korea. Korean Fam Resour Manage Assoc, 2008, 12: 159-176.

8) Kim AN, Song MY, Bae SH, et al.: Analysis of articles published in the Korean Journal of Oriental Medical Prescription. Korean J Orient Med Prescription, 2010, 18: 57-77.

9) Seong HK, Lee OH, Yu HK: Analysis of articles and citations in the Journal of the Korean Society of Clothing and Textiles. J Korean Soc Cloth Text, 1994, 18: 692-703.

10) Seo YM, Chang GT, Kim JH: Analysis of articles published in the Journal of Korean Oriental Pediatrics. J Korean Orient Pediatr, 2004, 18: $247-272$.

11) WCPT: Programme Guide Book. World Confederation for Physical Therapy CONGRESS 2015 Singapore, 2015.

12) Kang JI, Jeong DK, Choi H: A survey on awareness of physcial therapists about cardiopulmonary physical therapy. J Kor Phys Ther, 2014, $26: 202-208$.

13) Marchal-Crespo L, Reinkensmeyer DJ: Review of control strategies for robotic movement training after neurologic injury. J Neuroeng Rehabil, 2009 , 6: 20. [Medline] [CrossRef]

14) Yoo DH, Kim SY: Effects of upper limb robot-assisted therapy in the rehabilitation of stroke patients. J Phys Ther Sci, 2015, 27: 677-679. [Medline] [CrossRef]

15) Nakagawa KI, Nobuaki NR, Sakamoto M: The effect of a health promotion program consisting of easy and simple exercises for community living elderly people. J Phys Ther Sci, 2007, 19: 235-242. [CrossRef]

16) Sun WD, Lee SY, Kim DJ, et al.: Situations of health care service system for older persons and Its policy issues. Korea Institute for Health and Social Affairs, 2014, 22-9-1: 1-197. 